\title{
Imparting SEAM and the Four Essential Steps in Schools of Business and Management
}

\author{
Kelly La Venture \\ Bemidji State University, College of Business, USA
}

\begin{abstract}
This article examines differences between traditional management theory and the SocioEconomic Approach to Management (SEAM) along with their costs and implications in so doing; it focuses on how the Fredrick Taylor, Henri Fayol, and Max Weber (TFW) virus infects the workplace through mismanagement and through reinforcement of traditional management practice. Further, it explores imparting the four essential steps with learners and SEAM as a new approach to education in business academia and practice. This article charts a new direction by promoting global and interdisciplinary conversations about SEAM and the four essential steps as a practical way to transform learning in the workforce and in schools of business and management.
\end{abstract}

\section{Introduction}

News of student loan debt topping \$1 trillion [1] and recent-graduate unemployment rate of 8.5 percent [2] has sparked heated debate over the worth of a college education. This debate has initiated a wave of colleges and universities to freeze or lower tuition [3] rates. It has incited discussion over faculty power [4], standards for higher education [5], triggered reform amendments [6], and caused provocative comments and conversation about the value of higher education and reform in the news [7, 8] and amongst academicians and practitioners [9]. There are many opinions and interpretations of the politics, regulations, structures, and processes that have led to the current debate. And while there has been much conversation, there has been little agreement about what should change or how to make change. These interpretations and opinions have been voiced on television, in the newspaper, in scholarly journals, and on campuses world-wide - including in schools of business and management. The only consistent theme seems to be that something needs to change.

Change in schools of business and management is the focus of this article. This article examines traditional management theory to promote productive global and interdisciplinary conversation about the socio-economic approach to management (SEAM) as a practical way to transform learning in schools of business and management, and inform readers of its relevance in the workplace.

To begin, I review traditional management theory and something called the 'TFW virus' as a way to begin the conversation of why change is needed.

\section{Traditional management theory and the TFW virus}

In Western society, traditional management theory is taught in schools of business and management. The topic is frequently spoken about by faculty and written about in business and management textbooks. Specifically, three twentiethcentury theorists were seminal to methodologies of traditional scientific management: Frederick Taylor, Henri Fayol, and Max Weber. A brief review of their contributions follows.

Frederick Taylor (1856-1915) was an American engineer who developed the idea of scientific management, which shaped many generations of social scientists. He was a major influence in the creation of Harvard Business School. He stressed importance of the separation between the design and execution of work, and the study of how to obtain the maximum efficiency.

Henri Fayol (1841-1925), was a French engineer who developed the theory of administration. He emphasized specialization, division of work, the authority and responsibility of the boss to expect obedience, a hierarchical chain of command, and the importance of order.

Max Weber (1864-1920), a German sociologist, was known for developing the theory of bureaucracy. He posited that the ideology of organizational bureaucracy based on the definition of rules, which are then to be respected by the subjects under the bureaucracy. While individually each of these theorists was trying to engineer the most efficient workplace, 
together Taylor, Fayol, and Weber (TFW) shaped some of the core concepts of modern management theory [10].

In later years, creators of the socio-economic theory of organizations [11, 12] named this the TFW virus, in "tribute" to the promoters: Taylor, Fayol and Weber of their core concepts and the ideas that allowed the virus to manifest and grow in organizations [13]. Specifically, researchers at ISEOR, the Socio-Economic Institute of Firms and Organizations based in Lyon, France, identified the TFW virus to be the root cause of organizational dysfunction and flaws of the modern workplace [14].

\section{TFW virus in the workplace}

One overarching flaw prevalent in the modern workplace stems from traditional management practices. Traditional managers who subscribe to this theory see "people as a disposable commodity" [15] often referring to employees as human capital or human resources both verbally, and in organization documents and structures [15]. By objectifying employees, it becomes much easier for organizations and managers to mistreat employees. Mistreatment is defined by Harlos as "offensive behavior that is unsolicited and unwelcome and which violates...a fundamental right to respectful treatment” [16]. This mistreatment of employees by managers shows up in the form of incivility, bullying, social undermining, harassment, emotional abuse [17], and even violence [18].

Data collected by ISEOR [19] indicates that this mismanagement often leads to increased workers compensation cases, increased utilization of employee assistance programs, absenteeism, deviant behavior, organizational dishonesty [20], turnover, reduced product quality, poor customer service, and loss of employee engagement. In fact, disengagement in the U.S. workforce rose to $28 \%$ in only a year [21]. The Gallup (2013) "State of the American Workplace Report" classified $70 \%$ of the American workforces as disengaged with an annual cost of $\$ 450$ to $\$ 550$ billion [21].

Because employees are viewed as capital or resources they don't feel valued, appreciated, or as having autonomy. Further still, employees are often mismanaged, mistreated, and left to feel downright bad about themselves and their jobs, all as a result of how they are treated by managers infected with the TFW virus. TFW is a virus, which is "based on the basic assumption that people would be slavish and that throughout the world people would obey management" [22]. One can see why the old adage 'people quit their bosses, not their jobs' still applies.

Traditional managerial approaches lead to a host of larger implications on both the organization and the individual. The question is how did the manager learn to employ traditional management thinking and practice?

\section{How schools of business and management cultivate TFW}

We must examine the assumption that the manager learned to employ traditional management thinking and practice from a school of business or management. This way of thinking may have been promoted through the articles and textbooks the manager was assigned to read, his/her experiences with classroom and higher education organizational structure, and his/her observation of perceived authority figures - such as faculty - in/out of the classroom.

Not long ago, I opened a recently published marketing textbook. Predominantly displayed on one of the pages were Fayol's Fourteen Principles of Management. After reviewing several (old and new) business and management textbooks I found many references to the work of TFW theorists.

If a student attends a classroom lecture they are likely to hear faculty promote the work of TFW theorists as 'best practice' in management. Further still, you may observe these traditional management practices displayed in the classroom - such as, the faculty 'sage on stage' (imparting their wisdom on students) - in the course design, when working with or advising students, and through daily interactions. Just as managerial behavioral approaches influence employees, faculty behavioral approaches influence student learners.

After reading TFW infected texts, listening to TFW lectures, and observing TFW in the educational environment, learners may find themselves thinking like a traditional manager and employing traditional management practices in their professional careers. It is to no fault of the learner, as they learned and observed these theories as 'best practice' in management.

Of course, traditional management theory is not taught as 'best practice' in all schools of business and management or by all faculties. Moreover, this is not an argument that the work of the TFW theorists should not be discussed - it should. However, it must be placed in context. The history of management is of great importance and of significant value if you are open and "willing to study, challenge, and build on the theories" [14]. Many faculties in schools of business and management choose to do just that. These faculties know "the value of understanding is parallel to the common maxim about history; if one does not understand history, one is doomed to repeat it” [15].

However, if managers do learn to employ traditional management thinking and practice in a school of business or management, then an obvious 
link exists between the problems developing within the current workplace and what is being taught in schools of business and management.

\section{SEAM as the anti-virus of TFW}

There are alternatives to promoting traditional management thinking and practices. One alternative is to teach learners the socio-economic approach to management (SEAM). SEAM is a successful, methodical, tested approach to organizational change and assessing hidden costs making its way from France to the United States. "The fundamental hypothesis underlying the SEAM method is that performance results from the dynamics and quality of interaction between the different structures of the company (physical, organizational, technological, demographic and mental structures) and the behavior of the actors (at individual, team, activity group, categories and collective levels) [23].

The SEAM approach was developed in 1973 by Henri Savall, as an economic interrelation with sociotechnical systems. It is based in the SocioEconomic Institute of Firms and Organizations (ISEOR), a research center in the field of management located in Lyon, France. The Center was established in 1975 as a nonprofit organization associated with the University of Lyon 3 and IAE Business School.

The SEAM "theory draws on experiments and consists of 1.6 million hours of intervention research. Two thirds of the time involved with this research was spent within companies" [23]. SEAM is a dynamic and integrative model not intended to contradict management methods that are already used, but to confirm that SEAM has potential to integrate methods into a system-wide framework [25]. "The ISEOR approach has been to quietly demonstrate the legitimacy of the socio-economic validity of SEAM" [15].

Drs. John Conbere \& Alla Heorhiadi, the only ISEOR certified practitioners of SEAM in the United States stated, explained "SEAM approach is a complex theory-building research done in the postpositivistic epistemology within a social constructionist ontology using both qualitative and quantitative methods of data collection and analysis (using the SEAM language, 'qualimetrics')" [15]. They add that as "SEAM research lies within the social constructionist ontology; it is a legitimate positivistic research for management sciences” [15]. "SEAM challenges the accuracy of traditional accounting as taught in business and management schools, which leaves out some of the human elements that shape organizational profit and loss" [15]. "By using a different accounting system that provides a better scope of actual and hidden costs, people change their values and beliefs about what is right” [15]. SEAM bridges a qualitative interview and observation process with hidden cost accounting and economic analysis of the organizations strategy. It uses a basic four-leaf clover intervention model (Figure 1) to link accounting, economics, and a distinctive sociotechnical systems approach to large scale organizational change.

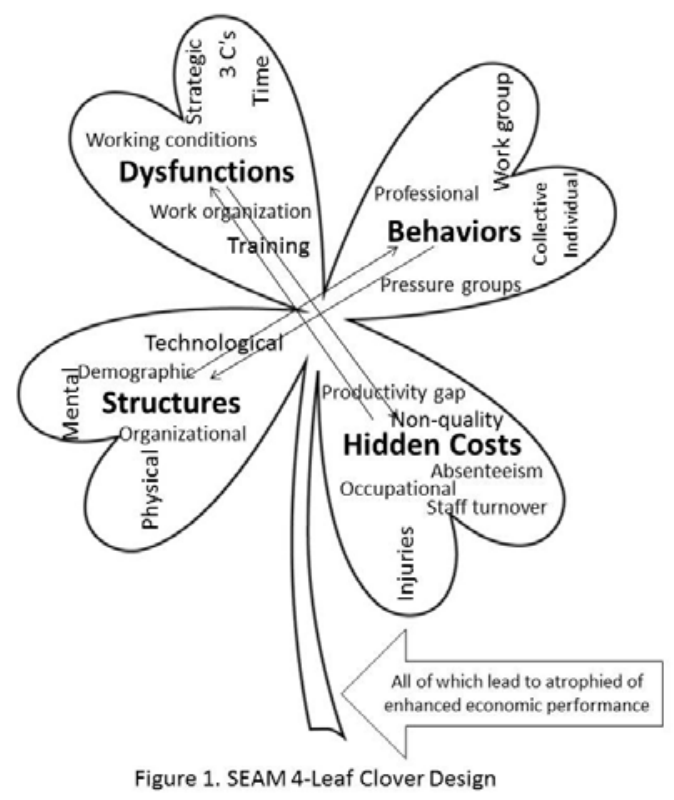

One way SEAM is unique from other approaches to organizational change, is that it "is based on a set of values and a belief system about management that is different from traditional management premises" [13]. The purpose of SEAM is to work to maintain a healthy society while earning a profit [15].Whereas traditional management beliefs suggest "the purpose of business is to earn money, and by corollary, the purpose of managing is to earn money for self and business" [15].

With SEAM, traditional managers learn to think and behave differently. SEAM values insist that the cause of employees' poor productivity begins with the way these employees are managed" [13]. Conbere \& Heorhiadi [15] note, SEAM founder "Henri Savall believes it is possible to change people's beliefs through practice”. This practice may come in the form of new management education and imparting the four essential steps as a way to change learner's values and belief systems about managing people.

\section{New management education and imparting the four essential steps}

Open for discussion is the idea of educating learners to the SEAM approach, and imparting the four essential steps with learners as a way to change learner's values and belief systems about managing people. Many managers believe there is a positive correlation between staff engagement and innovation and profitability [24]. If (a) bad management results 
in low staff engagement and low productivity, (b) and staff engagement results in innovation and profitability, and (c) SEAM results in high staff engagement, high productivity, and increased innovation and profitability, then (d) schools of business and management should consider teaching SEAM vs. traditional management approaches.

While teaching SEAM is a significant paradigm shift for traditional schools of business and management, SEAM may help future leaders to (a) embrace people-first values, (b) think and behave differently, thus (c) effectively manage their employees, and (d) subsequently positively impact the effectiveness of the organizations that employ them.

All people, whether consciously aware or not, have inherent core values that are deeply ingrained and guide their actions. These values set us apart from others and shape our identities. Indeed, to change these values and succeed in helping future managers learn to think and behave differently, it will take guts, practice, and potentially some emotional pain.

To create lasting behavior change, a person must change their underlying values and assumptions. Similar to most difficult paths in life, you cannot just teleport yourself from point A to point B (at least not yet!). Thinking and behaving differently often happens as a result of individuals learning about, and then going through the four essential steps:

1. Critical reflection of self-behavior

2. Identification of values or assumptions underlying the behavior

3. Changes in underlying values or assumptions

4. Change in the behavior [25].

Over time, these steps lead to transformative learning, a process wherein individuals change their mental models [26] and gain the "know how" to work through the four essential steps again when needed.

For example a student arrives on the first day of class with what some might call a 'chip' on her shoulder. She is soon labeled by her peers as having a 'bad attitude' as they observe her constantly rolling her eyes, crossing her arms, disrespectfully challenging faculty and classmates, and disrupting class. She is generally not liked. As a result of this behavior, the group dynamics change and the group's learning is hindered.

Over the course of the semester students learn about values, behavior, culture, critical reflection, self-awareness, and more. As they learn about each topic area, they also engage in activities designed to help them develop their own self-awareness and challenge their values and belief system. Before long, they are working their way through the four essential steps. Eventually, this particular student stops rolling her eyes and begins participating in a more constructive way. She starts asking meaningful questions and stops being disrespectful. At one point, she breaks down crying as she describes her militaristic upbringing and how over the years she steeled herself from forming relationships because she had to move so frequently. She was raised to have 'thick skin' and 'be tough' or be punished. Through deep reflection she begins to challenge and change her values and assumptions, accept that she has been part of the problem, and eventually changed her behavior. As a result, her relationships and her experiences at home, school, and work changed for the positive. Once hated by her peers and employees, she is now an effective and well liked manager.

At the core of SEAM is the goal of changing manager's beliefs to make them more effective. SEAM is traditionally used as an approach to large scale organizational change, affectionately as the anti-virus to TFW. There will likely always be a need for the antivirus, but as with most epidemics the goal is ultimately to eradicate them. Teaching the SEAM approach and imparting the four essential steps in schools of business and management just might be the answer to a TFW free workplace.

\section{Conclusion and implications}

In Western society, the destructive beliefs about managing people have been widely taught in schools of business and management. These ideologies have harmed organizations, infecting them with the TFW virus. The causes of many problems and hidden costs in organizations are due to negative behavior of management towards their employees, and lack of cooperation between people [27]. Most often, this behavior is learned in schools of business and management, mirrored by peers and direct reports, and consequently infects the entire organization. Creating better workplace environments begins with the thinking and practice that future managers learn to employ.

Teaching the SEAM approach in schools of business and management and imparting the four essential steps with learners is one way to change the thinking and practice of future managers. This shift will ultimately make organizations more effective. SEAM is not a panacea in itself, an exciting discovery, or a passing fad. SEAM is a methodical approach, an antivirus, and a solution based on a set of values and a belief system about management that is different from traditional management principles. It is a premise that is a valuable approach to education in Western business schools. Instead of relying on SEAM as THE antivirus to TFW, consider it a useful tool to educate future leaders. 


\section{Acknowledgements}

Drs. Rajat Panwar and Chantal Norrgard for support guidance and dedication to excellence

\section{References}

[1] Leonhardt, D. (2014) 'Is College Worth It? Clearly, New Data Say’, The New York Times; http://www.nytimes.com/2014/05/27/upshot/iscollege-worth-it-clearly-new-data-say.html (1 December 2014).

[2] Sturt, Kirsten. (2014). 'Is College Worth it Anymore', Huffington Post; http://www.huffingtonpost.com/2014/11/04/collegecost-benefit_n_6057262.html (28 November 2014).

[3] Marcus, J. 'College Tuition: More Campuses Freeze or Cut Tuition as Backlash Continues', Huff Post Education: The Hechinger Report; http://www.huffingtonpost.com/2012/10/05/collegetuition-more-camp_n_1942736.html (26 November 2014).

[4] Martin, R. E. 'College Costs Too Much Because Faculty Lack Power', The Chronicle of Higher Education; http://chronicle.com/article/CollegeCosts-Too-Much-Because/133357/ (26 November 2014).

[5] Barnds, W. K. 'Does Lowering Cost Mean Lower Standards for Higher Education?’ Huff Post College; http://www.huffingtonpost.com/w-kentbarnds/college-tuition-freeze-_b_2688104.html (26 November 2014).

[6] Australia Government Department of Education (2014). 'Higher Education and Research Reform Amendment Bill 2014'; reform bill https://education.gov.au/news/higher-education-andresearch-reform-amendment-bill-2014 (28 August 2014).

[7] Carey, K. (2013). 'Higher-Education Reform: a Legacy for Obama', The Chronicles of Higher Education; http://chronicle.com/article/HigherEducation-Reform-a/136737/ (21 January 2013).

[8] Kelly, A. (2014). 'The Thorny Politics of Higher Education Reform', Forbes; http://www.forbes.com/sites/akelly/2014/03/31/thethorny-politics-of-higher-education-reform/ March 2014).

[9] Dawkins, P. (2014). 'Why the Higher Education Reforms Need to be Independently Overseen', The
Conversation; http://theconversation.com/why-thehigher-education-reforms-need-to-be-independentlyoverseen-34231 (17 November 2014).

[10] A. Heorhiadi, J. P. Conbere and C. Hazelbaker. "Virtue vs. Virus: Can OD Overcome the Heritage of Scientific Management.” OD Practitioner, 2014, pp. 27-31.

[11] Savall, H. Enrichir le Travail Humain: L'Evaluation Economique, Preface de Jacques Delors. Paris: Bordas. Spanish translation: Por un Trabajo mas Humano; Madrid, Techniban, 1977. English edition: Work and people: An economic evaluation of job-enrichment, foreword by Ansoff, H.I.; NY: Oxford University Press, 1981. First published as a Ph.D. dissertation, University of Paris, Dauphine, 1973.

[12] Savall, H. and V. Zardet, Mastering Hidden Costs and Socio-economic Performance. Charlotte, NC: Information Age Publishing (First published in 1987), 2008.

[13] J. P. Conbere and A. Heorhiadi. 'SocioEconomic Approach to Management: A Successful Systemic Approach to Organizational Change.” OD Practitioner, 2011, pp. 6-10.

[14] Hazelbaker, C. B. (2014). Looking for Evidence of the TFW Virus. Doctoral dissertation. http://ir.stthomas.edu/caps_ed_orgdev_docdiss/36/

[15] J. P. Conbere and A. Heorhiadi. 'Some Epistemological, Ethical and Theological Aspects of SEAM', http://www.seaminc.com/wpcontent/uploads/SEAM-Epistemology.pdf November 2014).

[16] K. Harlos. "If you build a remedial voice mechanism, will they come? Determinants of voicing interpersonal mistreatment at work." Human Relations 63(3), 2010, pp 311-329.

[17] S. Hershcovis. "Incivility, social undermining, bullying...oh my! A call to reconcile constructs within workplace aggression research.” Journal of Organizational Behavior 32(3), 2011, pp. 499-519.

[18] L. M. Cortina, V. J. Magley, J. H. Williams JH and R. D. Langhout. "Incivility in the workplace: Incidence and impact” Journal of Occupational Health Psychology 6(1), 2001. Pp. 64-80.

[19] Savall, H. and V. Zardet, Mastering Hidden Costs and Socio-Economic Performance, Information Age Publishing, North Carolina, 2008. 
[20] R. B. Cialdini, P. K. Petrova, and N. J. Goldenstein. "The Hidden Costs of Organizational Dishonesty”, MIT Sloan Management Review, 2004, pp. 67-73.

[21] Gallup.

http://www.gallup.com/strategicconsulting/163007/st ate-american-workplace.aspx. 2013.

[22] V. Cristallini and H. Savall. "The TaylorismFayolism-Weberism Virus.” Facilitating the SocioEconomic Approach to Management: Results of the Frist SEAM Conference in North America, 2014, pp. 3-12.

[23] M. Bonnet and H. Savall. "The History of SEAM.” Facilitating the Socio-Economic Approach to Management: Results of the Frist SEAM Conference in North America, 2014, pp. 3-12.

[24] H. Stewart. "Do Happy Staff Make for Happy Customers and Profitable Companies?” Journal of Direct, Data, and Digital Marketing Practice, 2010, pp. 275-280.

[25] La Venture, K. "How the Discipline of Energetics Fosters Double-loop Learning: Lessons from Multiple Positivistic Case Studies” (Doctoral dissertation), 2013. Available from ProQuest Dissertations and Theses database.

[26] A. Heorhiadi, K. La Venture, and J. P. Conbere, "What Do Organizations Need to Learn to Become Learning Organizations?” OD Practitioner, 2014, pp. 5-9.

[27] V. Cristallini. "The Role of Governance in the Fight Against the Global Pandemic of the Technoeconomic virus", 8ème Congrès de l'ADERSE (Association pour le Développement de l'Enseignement et de la Recherche sur la Responsabilité Sociale de l'Entreprise), organisé par l'Université Paris Descartes, 2011. 